\title{
Keefektifan Model Pembelajaran Terpadu Tipe Sequenced Berbantu Media Puzzle Terhadap Hasil Belajar Siswa
}

\author{
Emi Zulfa ${ }^{*}$, Harto Nuroso ${ }^{2}$, Fine Reffiane ${ }^{3}$ \\ ${ }^{123}$ Fakultas Ilmu Pendidikan Universitas PGRI Semarang
}

\begin{abstract}
Abstrak
Penelitian ini dilatar belakangi dari hasil belajar siswa yang rendah dangaya mengajar guru yang konvensional. Guru seringkali tidak menggunakan media dan model pembelajaran dalam menyampaikan pelajaran. Tujuan dari penelitian ini yaitu untuk mengetahui apakah terdapat perbedaan hasil belajar siswa yang mendapat model pembelajaranterpadu tipe Sequnced berbantu media Puzzle. Metode penelitian yang digunakan yaitu metode penelitiantrue experimental dengan jenis posttest only control design dan diberikan perlakuan berupa model pembelajaran terpadu tipe Sequenced berbantu media Puzzle untuk kelas eksperimen ,dan kelas kontrol tanpa diberi perlakuan. Subjek penelitian ini adalah siswa Kelas IV SDN Tlogosari Kulon 01 Semarang.
\end{abstract}

Kata Kunci:

Hasil belajar, Puzzle, Sequenced

Keywords:

Learning outcomes, Puzzle, Sequenced teacher teaching styles. Teacher often do not use media and learning models in delivering learning.The ourpose of this study is to find out whether are differences in learning outcomes of student who get integrate learning models Sequenced by type of media puzzle. The research method used is the method true experimental with type posttest only control design. The subjects of this study were the fourth grade students of SD N Tlogosari Kulon 01 Semarang. 


\section{PENDAHULUAN}

Pendidikan adalah kehidupan, untuk itu kegiatan belajar harus dapat membekali peserta didik dengan kecakapan hidup (life skill atau life competency) yang sesuai dengan lingkungan kehidupan dan kebutuhan peserta didik (E. Mulyasa, 2016:4). Dalam Undang-Undang Nomor 20 Tahun 2003 tentang Sistem Pendidikan Nasional, Pasal 1 angka 1 menyatakan bahwa pendidikan adalah usaha sadar dan terencana untuk mewujudkan suasana belajar dan proses pembelajaran agar peserta didik secara aktif mengembangkan potensi dirinya untuk mengembangkan potensi dirinya untuk memiliki kekuatan spiritual keagamaan, pengendalian diri, kepribadian, kecerdasan, akhlak mulia, serta keterampilan yang diperlukan dirinya, masyarakat bangsa dan negara.

Beradasarkan Undang-Undang Sistem Pendidikan Nasional No. 20 Tahun 2003 menyatakan bahwa Pendidikan Nasional bertujuan untuk mengembangkan potensi peserta didik agar menjadi manusia yan beriman dan bertakwa kepada Tuhan Yang Maha Esa, berakhlak mulia, sehat berilmu, cakap, kreatif, amndiri dan menjadi warga negara yang demokratis serta bertanggung jawab.

Kemajuan suatu bangsa ditentukan oleh kualitas sumber daya manusia, sedangkan kualitas sumber daya manusia tergantung pada kualitas pendidikannya.Peran pendidikan sangat penting untuk menciptakan masyarakat yang cerdas, damai, terbuka dan demokratis. Oleh karena itu pembaharuan pendidikan harus selalu dilakukan untuk meningkatkan kualitas pendidikan suatu bangsa.

Pemerintah yang merupakan penyelenggara pendidikan melakukan berbagai upaya dalam peningkatkan mutu pendidikan nasional, seperti: mengadakan pelatihan, menyejahterakan kehidupan pendidik sampai merenovasi kurikulum. Perubahan kurikulum baru ini terjadi ialah perubahan dari kurikulum tingkat satuan pendidikan (KTSP) tahun 2006 menjadi kurikulum 2013.Kurikulum 2013 dirancang dengan harapan adanya perubahan kurikulum dapat meningkatkan mutu pendidikan nasional.

Kurikulum 2013 menjadi harapan baru bagi perkembangan pendidikan di Indonesia. Hal tersebut dikarenakan kurikulum 2013, siswa dijadikan sebagai subjek pembelajaran, dimana siswa dalam pembelajaran akan memberi pengalaman langsung kepada siswa. Selain itu, kurikulum 2013 menggunakan pembelajaran secara tematik untuk memberikan pembelajaran yang saling berkaitan.

Kurikulum 2013 menitikberatkan pada pencapaian 4 domain kompetensi yang terbagi atas: kompetensi spiritual, kompetensi sikap, kompetensi pengetahuan dan kompentensi keterampilan. Empat kompetensi tersebut dihasilkan dan berkembang dalam suatu proses pembelajaran. Kurikulum 2013 mengutamakan pembelajaran yang berpusat pada peserta didik tanpa mengabaikan peran/tugas pendidik di kelas, agar meningkatnya kemandirian dan kreativitas peserta didik.Efek dari perubahan kurikulum yang sangat dirasakan ialah adanya beberapa mata pelajaran yang disampaikan secara bersamaan (terpadu).

Model sequenced adalah model pembelajaran terpadu yang menekankan pada urutan karena adanya persamaan-persamaan konsep, walaupun mata pelajarannya berbeda (Forgarty, dalam Candra 2016). Hamalik (2008:48), menyatakan bahwa model sequenced adalah susunan atau urutan pengelompokan kegiatan atau langkah-langkah yang dilakukan dalam perencanaan kurikulum dengan lebih mengacu pada "kapan" dan "dimana" pokok-pokok bahasan tersebut ditempatkan dan dilaksanakan.

Menurut Fogarty dalam Candra (2016) manfaat dari model pembelajaran terpadu tipe urutan adalah pendidik dapat menyusun kembali rangkaian topik, bab dan unit dengan menentukan skala prioritas mata pelajaran yang ada pada kurikulum atau tidak sekedar mengikuti urutan yang telah dijabarkan di dalam kurikulum.

Media adalah pengantar pesan dari pengirim ke penerima pesan dengan demikian media merupakan wahana penyalur informasi belajar atau penyalur pesan.Rusman (2017:214) mendefinisikan "media sebagai segala bentuk dan saluran yang digunakan orang untuk menyalurkan pesan/informasi."

Menurut Djamarah dan Azwan Zain (2010:121)Media pembelajaran adalah alat bantu apa saja yang dapat dijadikan sebagai penyalur pesan agar tercapai tujuan pembelajaran.

Menurut Al-Azizy dalam Danang Sucahyo (2013) media puzzle merupakan suatu media pembelajaran berupa potongan-potongan gambar yang disusun hingga terbentuk menjadi gambar yang utuh. Pemilihan media puzzle selain menarik dan dapat memusatkan perhatian siswa.

Berdasarkan wawancara yang dilakukan dengan guru kelas IV yaitu Ibu Wuny, S.Pd di SDN Tlogosari Kulon 01, Pembelajaran yang diterapkan belum menggunakan variasi model dalam mengajar. Pembelajaran masih menggunakan pengajaran konvensional dan belum memanfaatkan media sebagai alat bantu untuk mengajar. Sehingga proses pembelajaran kurang berjalan optimal, dalam pembelajaran siswa pasif dalam mengikuti proses pembelajaran .

Fokus penelitian ini adalah mengetahui keefektifan model pembelajaran terpadu tipe Sequnced berbantu media Puzzle terhadap hasil belajar siswa kelas VI SDN Tlogosari Kulon 01 Semarang. 
Manfaat dari penelitian ini adalah untuk mengetahui seberapa efektif model Sequenced berbantu media Puzzle diterapkan di Sekolah Dasar.

\section{METODE PENELITIAN}

Penelitian ini dilaksanakan di SD Negeri Tlogosari Kulon 01 berlokasi di Kota Semarang, objek penelitian adalah siswa kelas IV. Dalam Penelitian ini menggunakan metode eksperimen dengan tujuan untuk melihat akibat dari suatu perlakuan. Pada penelitian eksperimen ini peneliti melakukan perlakuan dengan melakukan pembelajaran menggunakan media Puzzle. Akibat dari perlakuan tersebut adalah hasil belajar tematik siswa kelas IV SDN Tlogosari Kulon 01 Semarang.

Desain penelitian yang digunakan dalam penelitian ini adalah desain eksperimen.Penelitian ini menggunakan bentuk menggunakan Quasi Experimental Design dengan jenis Nonequivalent Control Group Design. Desain ini hampir sama dengan pretest-posttest control group design, hanya saja dalam desain ini terdapat dua kelompok yang tidak dipilih secara random. (Sugiyono, 2015: 116).

Penelitian ini menggunakan dua kelompok yaitu kelompok eksperimen dan kelompok kontrol . Kelompok eksperimen adalah kelompok yang diberi perlakuan (X), sedangkan kelompok yang lain tidak. Kelompok yang tidak diberi perlakuan disebut kelompok control (Y). Prosedur pengumpulan data merupakan langkah yang utama karena tujuan dari penelitian ini untuk mendapatkan data.

Teknik Pengumpulan Data pada penelitian ini yaitu: 1) Wawancara, Sugiyono (2017:194) Wawancara digunakan sebagai teknik pengumpulan data apabila peneliti ingin melakukan studi pendahuluan untuk menemukan permasalahan yang harus diteliti, dan juga apabila peneliti ingin mengetahui hal-hak dari responden yang lebih mendalam dan jumlah respondennya sedikit/kecil.

Dalam teknik wawancara ini menggunakan teknik mengumpulkan data hasil nilai harian mata pelajaran tematik siswa, yang diketahui dari proses belajar mengajar yang dilakukan oleh guru kelas IV, dan mencari tahu masalah-masalah yang dihadapi oleh guru dalam pembelajaran tematik. 2) Tes, Tes merupakan serentetan pertanyaan yang digunakan untuk mengukur ketrampilan, pengetahunan intelegensi, kemampuan atau bakat yang dimiliki oleh individu atau kelompok (Arikunto 2013: 193).

Dalam penelitian ini peneliti menggunakan teknik postest untuk mencari data hasil belajar pada tes awal dan sebelum diberi perlakuan serta mencari data prestasi belajar tes akhir setelah diberi perlakuan (media puzzle). 3) Dokumentasi, Dokumentasi tidak kalah penting dari metode-metode lain adalah metode dokumentasi, yaitu mencari data mengenai hal-hal atau variabel yang berupa catatan, transkrip, buku, surat kabar, majalah, prasasti, notulen rapat, lengger, dan sebagainya (Arikunto 2013: 274).

Instrumen penelitian ini terdiri dari tes yang berisi soal dan perangkat pembelajaran seperti silabus, RPP, Kisi-kisi dan Evaluasi..

\section{ANALISIS DAN PEMBAHASAN}

Berdasarkan perhitungan hasil penelitian, maka pembahasan ini akan dijelaskan secara kuantitatif. Rata-rata nilai pretest yang diperoleh dari kelas kontrol adalah 68,03 sebanyak 18 siswa dinyatakan tuntas dan sebanyak 12 siswa dari jumlah keseluruhan siswa kelas IV yaitu 30 siswa dinyatakan tidak tuntas dalam mencapai batas Kriteria Ketuntasan Minimum (KKM) yaitu 70. Sedangkan rata-rata nilai pretest yang diperoleh dari kelas eksperimen adalah 66,467 sebanyak 16 siswa dinyatakan tuntas dan sebanyak 14 siswa dari jumlah keseluruhan siswa kelas IV yaitu 30 siswa dinyatakan tidak tuntas dalam mencapai batas Kriteria Ketuntasan Minimum (KKM) yaitu 70.

Rata-rata nilai posttest yang diperoleh dari kelas kontrol adalah 76,83 sebanyak 25 siswa dinyatakan tuntas dan sebanyak 5 siswa dari jumlah keseluruhan siswa kelas IV yaitu 30 siswa dinyatakan tidak tuntas dalam mencapai batas Kriteria Ketuntasan Minimum (KKM) yaitu 70. Sedangkan rata-rata nilai posttest yang diperoleh dari kelas eksperimen adalah 84,36 sebanyak 26 siswa dinyatakan tuntas dan sebanyak 4 siswa dari jumlah keseluruhan siswa kelas IV yaitu 30 siswa dinyatakan tidak tuntas dalam mencapai batas Kriteria Ketuntasan Minimum (KKM) yaitu 70.

Dengan perbedaan rata-rata dan ketuntasan pada kelas kontrol dan kelas eksperimen menunjukan bahwa terdapat perbedaan yang signifikan terhadap hasil belajar kelas IV SDN Tlogosari Kulon 01 Semarang pada tema cita-citaku subtema hebatnya cita citaku pembelajaran 1 setelah menggunakan model pembelajaran terpadu tipe sequenced berbantu media puzzle dalam kegiatan belajar mengajar.

Hal tersebut sudah dibuktikan dengan adanya analisis diperoleh sebesar 3,1787 sedangkan dengan $d b=n 1+n 2-2=30+30-2=58$ dan taraf signifikan 0,05, diperoleh $=1,6715$. Karena $>$ yaitu 3,1787 > 1,6715 maka ditolak dan diterima atau dapat juga dikatakan keefektifan penggunaan model pembelajaran terpadu tipe sequenced berbantu media puzzle efektif untuk meningkatkan hasil belajar 
siswa kelas IV SDN Tlogosari Kulon 01 Semarang, dapat dilihat dengan adanya rata-rata nilai awal kelas eksperimen 66,46 setelah diberi perlakuan menggunakan model pembelajaran terpadu tipe sequenced berbantu media puzzle rata-rata nilai siswa menjadi 84,36 .

Hal tersebut sudah dibuktikan dengan adanya analisis diperoleh sebesar 3,1787 sedangkan dengan $d b=n 1+n 2-2=30+30-2=58$ dan taraf signifikan 0,05 , diperoleh $=1,6715$. Karena $>$ yaitu 3,1787 > 1,6715 maka ditolak dan diterima atau dapat juga dikatakan keefektifan penggunaan model pembelajaran terpadu tipe sequenced berbantu media puzzle efektif untuk meningkatkan hasil belajar siswa kelas IV SDN Tlogosari Kulon 01 Semarang, dapat dilihat dengan adanya rata-rata nilai awal kelas eksperimen 66,46 setelah diberi perlakuan menggunakan model pembelajaran terpadu tipe sequenced berbantu media puzzle rata-rata nilai siswa menjadi 84,36 .

Dari fakta di lapangan penerapan model pembelajaran terpadu tipe sequenced di kelas IV SD N Tlogosari Kulon 01 Semarang terbukti dapat mengaktifkan siswa karena siswa antusias dalam pembelajaran semuanya berfikir dan berdiskusi kemudian mempresentasikan hasil diskusi di depan kelas secara bergantian, menciptakan interaksi antar sesama siswa melalui proses diskusi dan mempresentasikan hasil diskusi di depan kelas, memberikan kesempatan siswa untuk berfikir dan saling membantu untuk memecahkan masalah satu sama lain. Ditambah adanya media puzzle yang membuat pembelajaran semakin menarik sehingga siswa semakin aktif dan antusias dalam mengikuti kegiatan belajar mengajar. Media puzzle ini digunakan secara berkelompok setiap kelompok menyusun potongan puzzle yang berhubungan dengan materi yang disampaikan kemudian di sampaikan di depan kelas.

Hasil penelittian ini sama dengan hasil penelitian Muhsina, Werdhiana dan Pasaribu (2015), yang dinyatakan bahwa ada peningkatan hasil belajar setelah pembelajaran dengan model sequenced. Sama juga dengan hasil penelitian Khomsoh (2013) yang menggunakan media puzzle untuk meningkatkan hasil belajar siswa dalam pembelajaran ilmu pengetahuan sosial di sekolah dasar.

Berdasarkan uraian di atas dapat disampaikan dengan adanya model pembelajaran terpadu tipe sequenced berbantu media puzzle efektif untuk meningkatkan hasil belajar siswa kelas IV SD N Tlogosari Kulon 01 Semarang..

\section{KESIMPULAN}

Berdasarkan hasil penelitian yang dilakukan pada kelas IV di SDN Tlogosari Kulon 01 Semarang, ada perbedaan hasil belajar antara kelas eksperimen dan kelas kontrol, hasil belajar siswa meningkat serta ketuntasan siswa 86,6\%, maka dapat disimpulkan bahwa model pembelajaran terpadu tipe sequenced berbantu media puzzle efektif terhadap hasil belajar siswa kelas IV SDN Tlogosari kulon 01 Semarang.

Berdasarkan hasil penelitian dan kesimpulan tersebut di atas maka: 1) Kepada guru sekolah dasar sebagiknya bisa menggunakan beberapa model dan metode pembelajaran yang tepat dan bervariasi yang sesuai dengan materiyang hendak disampaikan guna menciptakan siswa yang aktif dan berprestasi. 2) Guru hendaknya mencoba menggunakan model pembelajaran terpadu tipe sequenced berbantu media puzzle sebagai alternatif untuk memudahkan siswa dalam memahami pembelajaran tematik khususnya pada tema cita-citaku subtema hebatnya cita-citaku

\section{DAFTAR PUSTAKA}

Arikunto, Suharsimi. 2010. Prosedur Penelitian SuatuPendekatan Praktik. Jakarta: PT. Rineka Cipta.

Arikunto, Suharsimi. 2013. Prosedur penelitian. Jakarta: Rineka cipta.

Candra, Y. P. (2016). Pengaruh Lembar Kerja Peserta Didik (LKPD) Berbasis Model Pembelajaran Terpadu Tipe Sequenced Terhadap Kompetensi Siswa Pada Mata Pelajaran IPA Kelas VII di SMP N 3 Pariaman. PILLAR OF PHYSICS EDUCATION, Edisi: Vol. 8. Oktober 2016. Diakses 8 September 2018.

Depdikbud. 2003. Undang-undang No 20 tahun 2003 tentang sisdiknas. Jakarta: Depdikbud.

Danang Sucahyo. 2012. Penggunaan Media Puzzle untuk Meningkatan Hasil Belajar di Sekolah Dasar. JPGSD Volume 01 Nomor 02 Tahun 2013, 0-216. Diakses 23 September 2018.

Dimyati dan Mudjiono. 2009. Belajar dan Pembelajaran. Jakarta: PT Rineka Cipta 
Djamarah, Syaiful Bahri dan Azwan Zain . 2010. Strategi Belajar Pembelajaran. Jakarta: PT Renika Cipta.

Hamalik, Oemar. 2008. Dasar-dasar Pengembangan Kurikulum. Bandung: PT Rosdakarya.

Khomsoh, R. 2013. Penggunaan Media Puzzle untuk Meningkatkan Hasil Belajar Siswa dalam Pembelajaran Ilmu Pengetahuan Sosial di Sekolah Dasar. PGSD FIP, Universitas Negeri Surabaya. Diakses 28 Desember 2018.

Muhsina, Werdiana, I.K. Pasaribu, M .2015. Pengaruh Pemberian Urutan Materi Sequenced terhadap Hasil Belajar Siswa .e-Jurnal Mitra Sains, Volume 3 Nomor 2, April 2015. Diakses Desember 2018.

Mulyasa, E. 2016.Pengembangan Implementasi Kurikulum 2013. Bandung: PT Remaja Rosdakarya.

Rusman. 2017. Belajar dan Pembelajaran. Jakarta: Kencana

Sugiyono. 2015. Metode Penelitian Pendidikan Pendekatan Kuantitatif, Kualitatif dan RnD. Bandung: Alfabeta.

Suyatno. 2009. Menjelajah Pembelajaran Inovatif. Sidoarjo:Masmedia Buana Pustaka.

Sugiyono. 2012. Metode Penelitian Pendidikan. Bandung: Alfabeta

Trianto. 2009. Mendesain Model Pembelajaran Inovatif-Progresif. Jakarta: Kencana Prenada Media Group. 